\title{
Sustainable apparel? Is the innovation in the business model? - The case of IOU Project
}

\author{
Miguel Angel Gardetti ${ }^{{ }^{*}}$ and Subramanian Senthilkannan Muthu ${ }^{2}$
}

\begin{abstract}
Since sustainability approaches to the apparel industry are based on incremental rather than transformative solutions, the prevailing business models need to be changed.

This paper will introduce the IOU Project as an example about disruptive business model in the apparel and fashion sectors. This case was selected since disruptive innovation requires an entrepreneurial mindset and spirit with close coordination and cooperation among all participants (JAMA 352:24-28, 2004). The analysis - which is based on the Clark, Osterwalder, and Pigneur's (2012) business model (personal) 'canvas' - puts special emphasis on the supply chain development and on the relationship developed between the initiative and its customers, as well as on whether or not it fostered a relationship between the customer and the artisans who were part of the supply chain.

To develop this case, the authors collected background and qualitative and quantitative information of the company from its participation in the Best Performance in Sustainable Luxury in Latin America Award, getting this award in the category 'Best Fashion and Accessories Enterprise of Sustainable Luxury' in the 2011 edition. This source was supplemented with the chapter written by Kavita Parmar (2014) in the book entitled Sustainable Luxury and Social Entrepreneurship - Stories from the Pioneers, whose editors were Miguel Angel Gardetti and María Eugenia Girón (2014). Moreover, the authors considered the e-mails exchanged with Ms. Parmar within the framework of the above award.

Using a disruptive business model, the IOU Project manages to develop a value chain based on craftsmanship. Craftsmanship breathes humanity into objects, allowing the individual to create for the individual. In doing so, it translates the principles of knowledge, purpose, and timelessness into products that represent unique achievements (Ricca and Robins, 2012:53). Within this framework, supply chain management became a strong driver of value, for the IOU but for artisans and customers as well (Kell, 2010).

Finally, the IOU business model helps develop a strong relationship with consumers and artisans which dignifies the latter and appreciates their work.
\end{abstract}

Keywords: Social impacts; Environmental impacts; Supply chain; Disruptive; Sustainability; Innovation; Business models

\section{Background}

Any literature related to sustainable development refers or begins with the definition of sustainable development, which was defined as, 'development that meets the needs of the present without compromising the ability of future generations to meet their own needs' in Our Common Future, also known as the Brundtland Report, which was written in 1987 (World Commission on Environment and Development 1987). This definition has undergone many

\footnotetext{
* Correspondence: mag@sustentabilidad.org.ar

'Sustainable Textile Center, Av. San Isidro 4166 PB A, C1429ADP Buenos

Aires, Argentina

Full list of author information is available at the end of the article
}

critiques, as there were not many issues in the 80's which we are facing now; and we must say that if this report were written today, sustainable development would most likely be defined in a different way to portray the current situation. To define what sustainable development is all about is quite a common, though difficult, issue (Sneddon and Howarth 2006) and from the entrepreneurial point of view the elements under the umbrella of sustainability pollution prevention, resource productivity, environmental management, sustainable technology, social entrepreneurship, corporate social responsibility, human and labor rights, transparency, stakeholder management, among others - are increasing day by day. 
This same ambiguity of defining sustainable development prevails in the clothing and apparel sector, and it becomes more difficult to define what a sustainable apparel/clothing product is about, especially when it comes to the apparel sector. In the global economy, the role played by the world's garment and textile industry is significant, and the global turnover of this industry in 2011 was almost USD 3 trillion (including clothing, textiles, footwear, and luxury goods). This sector has significant levels of environmental and social impact, and it has not yet developed an overall vision to achieve sustainability up to the mark (Maximilian Martin, 2013; Muthu, 2014). The textiles and apparel sector comprises a lengthy supply chain, which is subject to mass environmental and social impacts.

Most of the current innovations in the apparel industry intended to achieve sustainability focus on raw materials (that is to say, eco-friendly raw materials) and products. Nevertheless, innovations are also being carried out in the process, logistics, recycling, and upcycling. Along this line, the World Economic Forum (2010) summarizes the limitations of current sustainability initiatives as follows:

current trends towards sustainability are welcome but inefficient. The shifts ... are focused on incremental, rather than transformative, change. While they may improve sustainability at the margins, they are rooted in a model of consumption that is itself unsustainable.

But very few innovations only focus on the total business model, which is the havoc of sustainable innovations of the current apparel sector.

There is a need to redefine dominant approaches to business in the apparel sector. Most industries are still characterized by a 'dig it up-use it-throw it away' production system which prevents the achievement of sustainable development in any meaningful way (Wells 2008: 85). Decades of talk about corporate social responsibility (CSR), corporate citizenship, corporate sustainability, and other related buzzwords have not radically changed this picture.

A transformation of dominant business models is therefore needed in order to achieve systemic changes toward sustainability. Rather than perceiving sustainability solely as compliance and risk management, businesses have to recognize the value-creating potential of sustainable business models. However, so far, literature that bridges business model and sustainability thinking is relatively scarce. Stubbs and Cocklin (2008: 103) argue that 'understanding of sustainable business models and how sustainable development is operationalized in firms is weak', and Schaltegger et al. (2011: 12) argues that 'Neither theoretical nor empirical research offers sufficient answers to the question what a sustainable business model might be'.
This work explores the potentials for building business models for sustainability through innovation or radical innovation through the analysis of the case called the IOU Project, created by the young entrepreneur Kavita Parmar, an e-commerce initiative that offers fashion-conscious consumers a very distinct platform. Clothes sold on the Web are designed and manufactured by European artisans. These clothes are based on hand-woven fabric typical of India -madras- made by Indian artisan knitters. Kavita Parmar's project was selected for the analysis since the disruptive innovation requires an entrepreneurial mindset and spirit with close coordination and cooperation among all participants (Rainey, 2004).

\section{Methods}

To develop this case, the authors collected background and qualitative and quantitative information of the company from its participation in the Best Performance in Sustainable Luxury in Latin America Award, getting this award in the category 'Best Fashion and Accessories Enterprise of Sustainable Luxury' in the 2011 edition. The criteria needed to be met to receive the award are:

-social aspects: the strategies carried out by the company underscoring positive impacts;

-environmental aspects: the strategies carried out by the company underscoring positive impacts;

-economic aspects: upfront investment; sales volume, profits (as a percentage of revenues), future growth expectations based on company performance, average price of product/s that your company sells, and distribution or sales channel

This source was supplemented with the chapter written by Kavita Parmar (2014) in the book titled Sustainable Luxury and Social Entrepreneurship - Stories from the Pioneers, whose editors were Miguel Angel Gardetti and María Eugenia Girón (2014). Moreover, the authors considered the e-mails exchanged with Ms. Parmar within the framework of the above award.

The analysis of the collected information focused on the business model based on the canvas presented by Clark et al. (2010). Even though this model not only applies to the clothing industry, it puts special emphasis on the supply chain development and on the relationship developed between the initiative and its customers. It was also analyzed if within the framework of the canvas the initiative fostered a relationship between the customer and the artisans who were part of the supply chain.

\section{(Disruptive) innovation and business models}

Innovation provides the means to create a new reality. It involves converting knowledge, learning, capabilities, 
and insights into value and creative new perspectives, products, productive outcomes, and business models. Innovation is more than change: it is making incremental and/or radical improvements to systems, technologies, products, processes, and practices (business models) (Rainey, 2004).

There are different types of innovation, namely sustaining, evolutionary, revolutionary, and finally disruptive (Christensen, 1997) innovation. Out of all of them, disruptive innovation is very much interesting and quite applicable to apparel industry. It is rather the need of the hour for today's apparel sector. Disruptive innovation is defined as innovation which helps creating a new market (and eventually disrupts an existing market) by implementing different value sets (Christensen, 1997; Christensen and Raynor, 2003; Christensen and Overdorf, 2004). Disruptive innovation refers not to the incremental improvement but rather to innovation that leapfrogs standard routines and knowledge (Hart and Milstein 1999). It is what Quinn (1996) called a much focused process - discontinuous with the past and generally irreversible. Thus, rather than simply seeking to reduce the negative impacts of their operations, firms can strive to solve social and environmental problems through the internal development or acquisition of new capabilities that address the sustainability challenge directly (Hart, 1997, 2005a, 2007 and Hart, 2003). It is what Rainey (2004) defined as moving from thought to action.

Disruptive technologies can bring to the marketplace a very different value proposition than previously available, and, most importantly, products based on disruptive technologies can be cheaper, simpler, and smaller and can be more frequently made and very convenient to use (Christensen, 1997; Aneja, 2010).

The business model concept has become increasingly used to provide explanations and tools for studying the dynamics of businesses (Amit and Zott, 2001; Zott et al., 2011). Several authors have proposed varying definitions and theoretical frameworks to explain business models. See for example the works of Perkmann and Spicer (2010), Osterwalder (2004), Osterwalder et al. (2005), and Teece (2010). Osterwalder and Pigneur (2010) have applied a pragmatic perspective to the concept that helps to understand how a firm does business, for analyses, comparison, performance assessment, management, and communication, and to assist firms in their innovation. Given this provenance, some concepts prioritize the creation of economic value for business (Chesbrough and Rosenbloom, 2002).

Lüdeke-Freund (2010) describes a sustainable business model as a business model that creates a competitive advantage through superior customer value and contributes to a sustainable development of the company and society. The business model concept has recently been employed in the context of sustainable innovation (Boons and Lüdeke-Freund, 2013, Wüstenhagen and Boehnke, 2008, Wells, 2008, Hannon et al., 2013).

A frequently used approach from Osterwalder and Pigneur (2010) deconstructs the business model into nine inter-related 'building blocks.' These blocks require:

-Customer segments: customers comprise the heart of any business model. An organization must take a conscious decision about which segments to serve and which segments to ignore. Once this decision is made, a business model can be carefully designed around a strong understanding of specific customer's needs. -Specification of the value proposition: the value proposition is the reason why customers turn to one company over another. The value proposition consists of a selected bundle of products and/or services that caters to the requirements of a specific customer segment. -Channels: are customers' touch points that play an important role in the customer's experience.

-Customer relationships: a company should clarify the type of relationship it wants to establish with customer segment. This relationship may be driven by customer acquisition, customer retention, and boosting sales. -Revenue streams: represents the cash a company generates from each 'customer segment'.

-Key resources: these resources allow an enterprise to create an offer a 'value proposition', reach markets, maintain relationship with 'customer segments', and earn revenues.

-Key activities: these are the most important actions a company must take to operate successfully.

-Key partnerships: companies create alliances to optimize their business models, reduce risk, or acquire resources.

-Cost structure: this is the most important cost incurred while operating under a particular business model.

Figure 1 shows the CANVAS model developed by Osterwalder and Pigneur (2010). It should be noted that since Osterwalder and Pigneur (2010) defined customers as the heart of any business model, we adjusted the original version, putting customers in the first place.

In 2012, Clark - with the cooperation of Osterwalder and Pigneur- adapted the concepts of the 2010 CANVAS to business models where the key resources are, basically, individuals (entrepreneurs), their skills and abilities, and the assets they own and control (Clark et al. 2012). Based on this adjustment, Figure 1 would be as follows (Figure 2).

\section{The IOU Project ${ }^{\mathrm{a}}$}

Kavita Parmar and Iñigo J. Puente Henales (her husband) created the IOU Project. With an investment of USD 2.5 million - between the founders and financial funders - and 


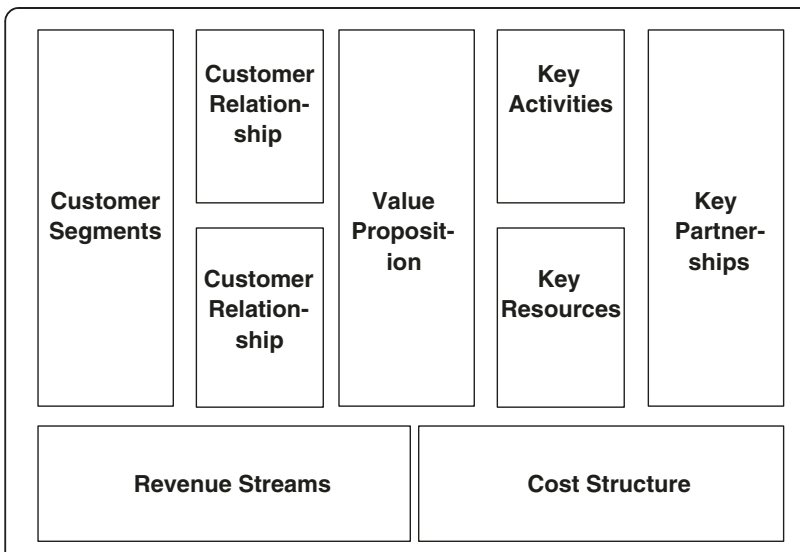

Figure 1 CANVAS model developed by Osterwalder and Pigneur (2010). Source: prepared and adapted by the authors (based on Osterwalder and Pigneur (2010)).

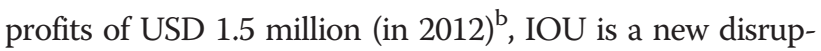
tive e-commerce initiative that offers fashion-conscious consumers a very distinct platform ${ }^{\mathrm{c}}$. This platform not only enhances the online experience by linking end buyers with artisan producers but also draws upon the most compelling aspects of social media to construct a community around its core brand values: authenticity, transparency, uniqueness, and both social and environmental responsibility. Born from the need to empower both the artisan and the consumer, it uses the full scope of modern technology and the social web by creating a new supply chain that we call the 'prosperity chain', and IOU expects a 100\% growth in the coming years based on the past years' performance.

The IOU's mission is to promote responsible consumption, whereby the consumer engagement is fundamental. People are already very much interested in the provenance of things; once they see who makes the product they use, there is an emotional value attached to knowing its true worth. This makes the product less disposable.

IOU is wholesaling the product directly to their consumers, which means that IOU can make the highest quality product paying the craftsman in India and Europe their fair share and still sell it at the same price as most 'high street retailers' so that the consumer gets great value at an affordable price tag. A comparable shirt made in Italy with handmade fabric would cost at least twice the price at the IOU's site. Prices range from USD 30 to 170.00. Thus, consumer's purchases are allowing these weavers and artisans in India and Europe to self-sustain and not have to migrate hundreds of miles to work in factories as laborers.

But, most importantly, IOU's impact is that it gives back 'pride' to the artisan's work; to date, these artisans have never had a chance to speak, let alone get connected with end consumers. In this relationship, the consumer can learn some things from the artisans and have access to a video that introduces them as well. For example, the weaver artisan R. Ramanathan ${ }^{\mathrm{d}}$ belongs to a cooperative called Kanjamanathanpettai Handloom Weavers Cooperative and has been a member of IOU since 26 September 2010. The website also shows some characteristics of the cooperative to which this artisan belongs. For instance, the year it was founded, how many artisans it employs and how many looms they have, etc. In turn, the weavers who are the members of the IOU Project - who have agreed to work with higher quality standards - receive economic compensation which is equal to $100 \%$ of their usual salary for each lungi ${ }^{\mathrm{e}}$ they knit. An interesting testimonial that shows the possibilities this relationship entails is that of Jessica Adams, a

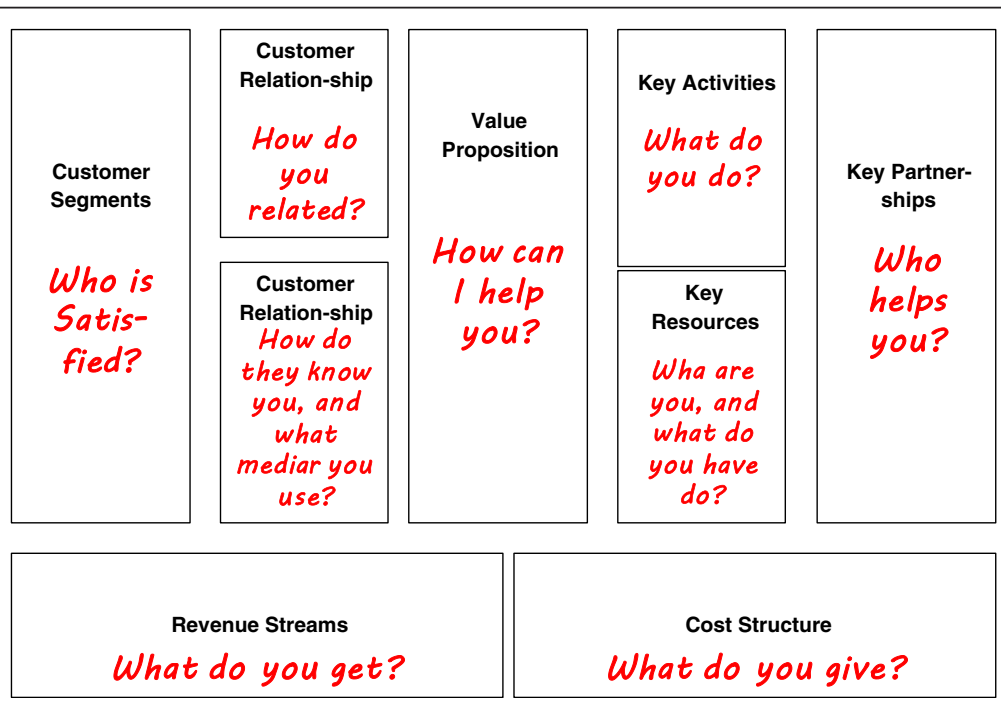

Figure 2 Personal CANVAS model developed by Clark et al. (2012). Source: prepared and adapted by the authors (based on Clark et al. (2010)). 
consumer and textile design student from the University College Falmouth (England), who visited Karaikadu Handloom Weavers Cooperative. On the last day of her visit, she said: 'It was a lovely day, the set up here seems to be working well and the weavers seem to be content. The atmosphere is so wonderful. I really hope to return one day, and wish all these wonderful people the best for the future...Hopefully this weaving way of life can continue'.

The IOWEYOU label has taken beautiful hand-woven 'Madras' plaid fabrics made for centuries by artisans in India and turned them over to artisans in Europe who create one-of-a-kind apparel items to be sold online via the IOU specialized social e-commerce tools, the 'trunk show host.' The affordable, easy-to-wear apparel items found on the site are handmade and unique, in every sense of the word.

On the IOU website, buyers can shop for unique items and have access to a wealth of audiovisual material that chronicles the process whereby an item was produced. End buyers also have the opportunity to 'become part of the story' of each item by using a unique QR code on the items which electronically links them to the specific artisans that created their unique piece. IOU has already expanded into other authentic fabric sources and artisan groups: the real indigo plant-dyed denim from Japan, real cashmere wool from Northern India/Nepal, and yak wool from Tibet, among others. All of them sourced from artisan communities with full traceability and transparency. The IOU big dream is to create a Wikipedia of artisans worldwide.

The IOU Project also offers partner retailers, and others brand the possibility of using the platform and the IOU's MAAP (mass aggregated artisan produced) system to produce their designs.

\section{Results and Discussion}

The IOU Project analysis through Clark, Osterwalder, and Pigneur's personal CANVAS (2012)

Below, we will analyze the case of the IOU Project based on Clark et al. (2012) CANVAS structure:

\section{Who is satisfied?}

IOU knew that there was a small part of the audience that cared about the ideas of traceability and transparency, but it is intended to reach out a larger audience. In Kavita's word: 'I was obsessed with the idea of addressing a larger market, that you could buy a piece at a reasonable price point and that it was truly unique felt like important sales arguments.' However, in order to increase its market share and promote craftsmanship, the IOU Project might consider the ideas stated by Lynn Stephen in her paper 'Export Markets and their Effects on Indigenous Craft Production: the Case of the Weavers of Teotitlán del Valle, México' (1996:382). The international market for crafts is built on a consumer ideology that contrasts manufactured, mass-produced, modern objects with handmade, authentic, and local crafts, which means that these artisans and traders do not necessarily have to adopt the norms of capitalist relations to operate in these markets (Lockwood 1993).

Here, the purchase goes beyond the object itself; excellence and devotion give both life and a sense of deep connection between individuals.

\section{How do you relate?}

According to the founder - Kavita Parmar: 'Each IOWEYOU Madras piece is unique and has an IOU code (QR Code) that takes you to its story simply by scanning it with a Smartphone or just entering the number on our website. On the site you can see the weaver who hand wove that particular fabric in India and then the artisan in Europe who turned that fabric into a beautifully handcrafted piece. We encourage the customer to take their picture and upload it to complete the story so that the weaver in India and the artisan in Europe can also see who bought that piece.' The founder of the IOU Project encourages consumers to 'become part of the story.' This is possible because consumers are not ignoring the price/quality ratio but are applying and prioritizing other criteria in their purchase decision process (Harrison et al., 2010:2).

\section{How do they know you and what media do you use?}

Iñigo J. Puente Henales - Kavitas' husband - is an engineer from MIT and has always had the belief that with the current technology, IOU could have the tools to truly disrupt the fashion industry. Kavita explains it like this, 'the consumer does care and the proof is in the pudding. Being a self-funded start up and this being a new idea that took a lot of time and resources to develop, when we went live we had no money left for marketing or PR. But people spread the word like wild fire. We continue to receive emails from people around the globe who love the idea and want to support us. Also we added the very consumer engaging trunk show host feature. Since as a company we were being disruptive with the current supply chain, why not take that one step further and do the same experiment with distribution of the brand. On our website people who are truly interested in the project can have their own trunk show.' This evidences that the IOU Project moved from the traditional 'brand-centric' concept to focus on a consumer wanting more direct communication and dialogue with the company. According to Rinaldi and Testa (2014), this revolution was inevitable given social networks and increasing transparency, thanks to the online presence of company information which might be of interest to the end consumer. 


\section{How can I help you?}

A 'story' as Kavita said, 'I wanted the first collection to be around an authentic story and what could be more authentic than Gandhi's non-violent revolution? He inspired millions of Indians to buy local handmade fabrics to fight against the cheaper machine-made imports from imperialistic $19^{\text {th }}$ century England to give back work to the local craftsman.' Sustainability is redefining the world of textiles and fashion. Therefore, the IOU Project offers a 'story' instead of a garment. That was precisely one of the seven demands addressed by young (undergraduate and postgraduate) students (from all over the world) during the Youth Fashion Summit, which were in turn submitted to the industry at the Copenhagen Fashion Summit, 2014.

\section{What do you do?}

Kavita explains it like this, 'In the last 20 years the focus of all factories and ateliers has been to increase productivity, as they had to compete with global sourcing. We had to go back to how things were made before when a very small, reduced group made the entire piece. This gave us better quality and traceability. What was magical was that it also gave back authorship and brought back pride to the artisan. Creating the online and offline traceability system was one of the most challenging tasks but it has also been the most rewarding. Making people aware of each other in the chain has been one of the true successes of the project, something that I cannot describe on a balance sheet but have witnessed repeatedly in the proud smiles of the artisans when they see the Prosperity Chain on the web. Our focus is on value and quality. There is a huge imbalance in people's perception of value. The industry has convinced the consumer to accept low quality for a cheaper price point and turned everything into a disposable product'.

By creating this prosperity chain, the IOU Project is sustaining artisans' deeply held beliefs about their social relations and their relationships to the environment (Grimes and Milgram, 2000: 7). This is so because their legitimacy as craft items hinges on the circumstances of their production as they are made using traditional craft techniques (Stephen 1996:393).

\section{Who are you and what do you have?}

Kavita Parmar is a self-taught designer and a serial entrepreneur. The IOU Project was born out of Kavita Parmar's frustration as a designer with the current fashion system. It is all about faster and cheaper; it has become a race to the bottom and does not nurture big design (not just making things pretty but truly designing the ecosystem around their production to make it sustainable) nor value provenance, excellent craftsmanship, or artisanship.
Fletcher and Grose (2012) analyzed the roles that should be played by designers within the sustainability framework, among which we find that of communicator, facilitator, and activist. Throughout the development of this project, Kavita Parmar is playing all of these roles. Moreover, she regard this as a 'cultural' project that gives a sustainable answer to artisans' employment and contributes to artistic preservation (Liebl, 2005).

\section{Who helps you?}

Focusing on what was most important to Kavita, the artisan who helped to make IOU designs a reality and the customer who bought them. So IOU worked on the first collection with handloom weavers from Tamil Nadu, which were founded in 1927 inspired by Mahatma Gandhi. But, in addition to this, IOU wanted to produce the clothing with the best makers and Europe with its artisanal tradition.

For the IOU Project, craftsmanship is an essential principle (while for its 'fans', it is an essential driver for their purchase decision). Craftsmanship is an essential part of the IOU Project's rationale. It is a value-creating differentiator. That is the reason why IOU features its products as 'unique' (each garment is presented as a one-of-a-kind creation). It is the world of unique tailormade products and limited editions. This concept brings customers closer to artisans.

\section{What do you get and what do you give?}

Using transparency and traceability, the IOU Project aims to turn the supply chain into what we call a prosperity chain: IOU buys from weavers and artisans at the fair price they ask and works on low mark-ups compared to the normal industry standards to ensure that the final price is competitive. Table 1 includes a summary of the main aspects of the IOU Project.

\section{Table 1 The main aspects of the IOU Project}

\begin{tabular}{|c|c|}
\hline & The IOU Project \\
\hline Size (sales) & $\$ 1,500,000.00$ \\
\hline Profit & Break even 2013/2014 \\
\hline $\begin{array}{l}\text { Expect growth based on } \\
\text { previous years }\end{array}$ & $100 \%$ \\
\hline Average price & $\$ 30-170$ \\
\hline Distribution & $\mathrm{B} 2 \mathrm{C}$ \\
\hline Investment & $\$ 2,500,000.00$ \\
\hline Investors & Founders + FF \\
\hline Social impact & $\begin{array}{c}\text { Building prosperity chains, where products } \\
\text { are embedded with full traceability from } \\
\text { artisan to consumer. Pride and higher } \\
\text { prices for craftspeople. }\end{array}$ \\
\hline Environmental impact & Locally grown cotton \\
\hline
\end{tabular}

Source: prepared by the authors. 


\section{Conclusions}

Most organizations - whether start-ups or established companies - take very defensive postures that protect and nurture all that which has served them well in the past, even in the face of change (Teece et al. 1997; Christensen, 1997). That is to say, they react by increasing their commitment to the 'existing' products, processes, and markets. However - according to Hart and Milstein (1999) - successful surviving companies or start-ups have been able to invest or partner in order to achieve new competencies and experience in new untapped markets. That is the difference between continuity and discontinuity as pointed out by Hart (2005b). The former is illustrated by concepts such as: efficiency, operations, control, resource allocation, and convergent thinking. The latter is illustrated by: imagination, innovation, creative destruction, resource attraction, divergent thinking. It is also what Milstein, Hart, and London (2007) called the 'revolutionary routines.' It is what Kavita Parmar understood by 'breaking' with the dominant system in the textile and fashion industries.

As a business model describes the rationale of how an organization creates, delivers, and captures value (Osterwalder and Pigneur, 2010: 14), a transformation of dominant business models is, therefore, needed in order to achieve systemic changes toward sustainability. Rather than perceiving sustainability solely as compliance and risk management, businesses have to recognize the valuecreating potential of sustainable business models. Using a disruptive business model, the IOU Project manages to develop a value chain based on craftsmanship. The dawn of this shift makes individual savoir-faire more important and valuable than ever. Craftsmanship is about women and men imagining and creating, failing and succeeding, searching and finding, and preserving and challenging and developing unique expertise in the process. It is, just as importantly, about the constant flow of such expertise from one generation to the next, across decades and centuries (Ricca and Robins, 2012: 53). Craftsmanship breathes humanity into objects, allowing the individual to create for the individual. In doing so, it translates the principles of knowledge, purpose, and timelessness into products that represent unique achievements (Ricca and Robins, 2012: 53). Within this framework, supply chain management became a strong driver of value, for the IOU but for artisans and customers as well (Kell, 2010). The IOU Project's approach includes associating with artisans to innovate and provide for sustainable win-win scenarios (Hammond, 2001; Prahalad and Hammond, 2002; Prahalad and Hart, 2002; Hammond 2004a, b; Hart, 2005a; Prahalad, 2005). Limitation of the analysis presented in this paper with the aid of IOU Project, this analysis is based on the perspective of the business owners without much reference to the artisans' perspective of how it works for them.

The IOU Project's business model helps to develop a strong relationship with consumers and artisans which dignifies the later and appreciates their work. Figure 3 shows these relationships within the framework of Clark et al. (2012) CANVAS: the blue arrow with number 1 shows the relationship that the IOU Project developed with its clients. The blue arrow with number 2 shows the relationship with consumers that share the same values that the IOU Project fosters. The light blue arrows with number 3 show the close relationship with artisans. And the arrows with number 4 show the relationship built between consumers and artisans through the IOU Project website.

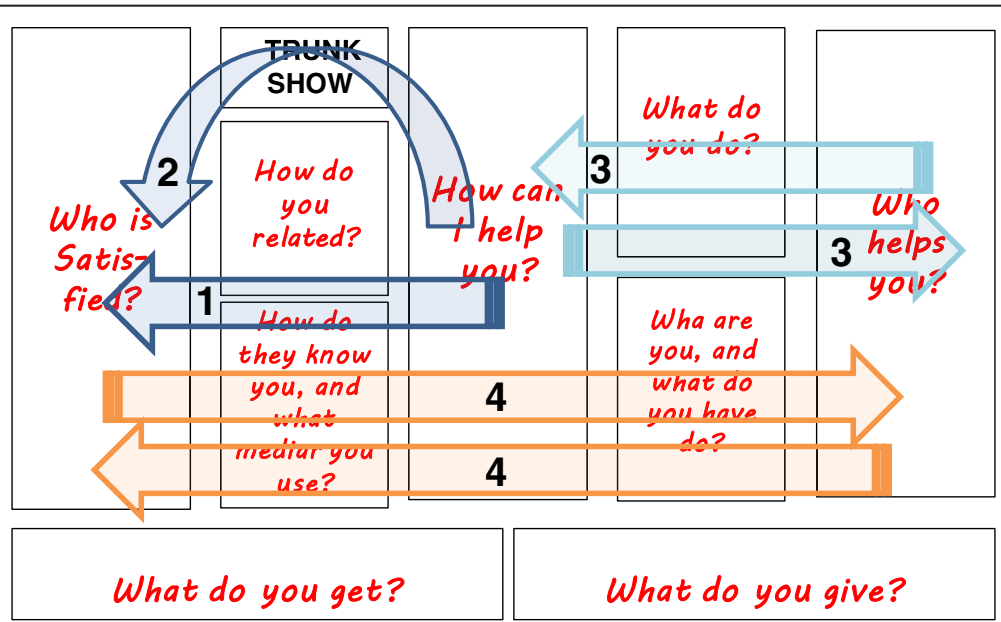

Figure 3 Relationships established by the IOU Project through the personal CANVAS model developed by Clark et al. (2012). Source: prepared and adapted by the authors (based on Clark et al. (2010)). 


\section{Endnotes}

${ }^{\text {aThis }}$ portion is based on Gardetti and Girón (2014) Sustainable Luxury and Social Entrepreneurship - Stories from the Pioneers; and information during the process of the second edition of 'Best Performance in Sustainable Luxury in Latin America Award' (at present IE Award on Sustainability in the Luxury and Premium Sectors at global level); and on exchange of e-mails with Mrs. Kavita Parmar - the IOU Project founder.

${ }^{b}$ IOU Project break even will be 2013/2014.

'IOU website: http://iouproject.com/

${ }^{\mathrm{d}}$ The IOU Project (2015): http://iouproject.com/stories/ weaver/ramanathan/ Accessed 5 Jan 2015.

eEach garment is made from a different woven piece, which is $2 \mathrm{~m}$ long, called lungi, also known as 'Madras' square. The lungi is $2 \mathrm{~m}$ long and has been woven in India by artisans for centuries.

\section{Competing interests}

The authors declare that they have no competing interests.

\section{Authors' contributions}

The authors read and approved the final manuscript.

\section{Author details}

'Sustainable Textile Center, Av. San Isidro 4166 PB A, C1429ADP Buenos Aires, Argentina. ${ }^{2}$ Sustainability Consultant, SGS (HK) Limited, Global Sustainability Services, Hong Kong.

Received: 10 September 2014 Accepted: 3 February 2015

Published online: 20 April 2015

\section{References}

Amit, R. and C. Zott (2001) Value creation in e-business. Strategic Management Journal, 22, 493-520.

Aneja, A, 2010., The art (and science) of propelling growth in textiles, 7th International Conference - TEXSCI 2010, September 6-8, Liberec, Czech Republic, Available at: http://wjoe.hebeu.edu.cn/sup.2010/Fibre\%20Science\% 20and\%20Smart\%20Textiles/9_o_Aneja.pdf

Boons, F, \& Lüdeke-Freund, F. (2013). Business models for sustainable innovation: state-of-the-art and steps towards a research agenda. Journal of Cleaner Production, 45, 9-19.

Clark, T, Osterwalder, A, \& Pigneur, Y. (2012). Business model you. New Jersey: John Wiley \& Sons.

Christensen, CM. (1997). The innovator's dilemma: when new technologies cause great firms to fail. Boston: Harvard Business Press.

Christensen, CM, \& Raynor, ME. (2003). The innovator's solution: creating and sustaining successful growth. Boston: Harvard Business Press.

Christensen, CM, \& Overdorf, M. (2004). Meeting the challenge of disruptive change. In RA Burgelman, CM Christensen, \& SC Wheelwright (Eds.), Strategic management of technology and innovation - fourth edition (pp. 541-549). New York: McGraw-Hill Irwin.

Chesbrough, HW, \& Rosenbloom, RS. (2002). The role of the business model in capturing value from innovation: evidence from Xerox Corporation's technology spinoff companies. Industrial and Corporate Change, $11,533-534$.

Fletcher, K, \& Grose, L. (2012). Fashion \& sustainability: design for change. London: Laurence King Publishing.

Gardetti, M.A. and M.E. Girón (eds) Sustainable Luxury and Social Entrepreneurs: stories from de pioneers. Greenleaf Publishing, Sheffield.

Grimes, KM, \& Milgram, DL. (2000). Introduction. In KM Grimes \& B Lynne Milgram (Eds.), Artisans and cooperatives: developing alternate trade for the global economy (pp. 3-10). Tucson: The University of Arizona Press.

Hammond, A. (2001). Digitally empowered development. Cooperation South Journal, 1(1), 5-15.
Hammond, A. (2004a). Unleashing entrepreneurship among the poor. Sustainable Development International, 12(1), 1-3.

Hammond, A. (2004b). Technology, globalization and the poor. Washington: World Resources Institute, Washington.

Hannon, MJ, Foxon, TJ, \& Gale, WF. (2013). The co-evolutionary relationship between energy service companies and the UK energy system: implications for a low-carbon transition. Energy Policy, 61, 1031-1045.

Harrison, R, Newholm, T, \& Deirdre, S. (2010). Introduction. In R Harrison, T Newholm, \& S Deirdre (Eds.), The ethical consumer (pp. 1-8). London: Sage.

Hart, SL. (1997). Beyond greening - strategies for a sustainable world. Harvard Business Review, 75(1), 66-76.

Hart, SL. (2005a). Capitalism at the crossroads. Upper Slade River: Wharton School Publishing.

Hart SL (2005b) Creative destruction y sustainability, lecture delivered within the framework of the Argentina Base of the Pyramid Learning Lab (Center for Study of Corporate Sustainability, Argentina, September 2005)

Hart SL (2007) Capitalism at the crossroads - capitalism at the crossroads - aligning business, earth, and humanity. 2nd ed. Wharton School Publishing, Upper Slade River

Hart, SL, \& Milstein, M. (1999). Global sustainability and the creative destruction of industries. MIT Sloan Management Review, 41(1), 23-33.

Hart, SL, \& Milstein, M. (2003). Creating sustainable value. Academy of Management Executive, 17(2), 56-67.

Kell, G. (2010). Prologo. In S Cody Sisco, C Bythle, \& P-J Peder Michael (Eds.), Supply chain sustainability: a practical guide for continuous improvement (p. 2). New York: United Nations Global Compact.

Liebl M (2005) Jodhpur: The most creative of communities. Paper presented at the Conference on Asia-Pacific Creative Communities: A Strategy for the $21 \mathrm{st}$ Century Senior Expert Symposium, Jodhpur February 22-26, 2005.

Lockwood, VS. (1993). Thaitian transformations: gender and capitalist development in a rural society. Boulder: Lynne Rienner.

Lüdeke-Freund F (2010) Towards a conceptual framework of business models for sustainability. ERSCP-EMSU Conference 2010 - Knowledge Collaboration and Learning for Sustainable Innovation. Centre for Sustainability Management (CSM), Leuphana University of Lüneburg.

Martin M (2013) Impact Economy, 2013, Creating sustainable apparel value chains: a primer on industry transformation. Suisse: Impact Economu. Available at: http://www.impacteconomy.com/papers/IE_PRIMER DECEMBER2013_EN.pdf

Milstein, M, Hart, SL, \& London, T. (2007). Revolutionary routines. In SK Piderit, RE Fry, \& DL Cooperride (Eds.), Handbook of transformative cooperation - new designs and dynamics. Stanford: Stanford University Press.

Muthu, SS. (2014). Assessing the environmental impacts of textiles and the clothing supply chain. UK: Woodhead Publishing.

Osterwalder A (2004) The business model ontology: a proposition in a design science approach. Institut d'Informatique et Organisation. Lausanne, Switzerland, University of Lausanne, Ecole des Hautes Etudes Commerciales HEC

Osterwalder, A, \& Pigneur, Y. (2010). Business model generation: a handbook for visionaries, game changers, and challengers. New Jersey: John Wiley.

Osterwalder, A, Pigneur, Y, \& Tucci, CL. (2005). Clarifying business models: origins, present, and future of the concept. Communications of the Association for Information Systems, 16(1), 1-25.

Parmar, K. (2014). The IOU Project. In MA Gardetti \& ME Girón (Eds.), Sustainable luxury and social entrepreneurship - stories from the pioneers. Sheffield: Greenleaf Publishing.

Perkmann, M, \& Spicer, A. (2010). What are business models? Developing a theory of performative representations. In: Nelson Phillips, Graham Sewell, Dorothy Griffiths (eds.) Technology and Organization: Essays in Honour of Joan Woodward. Research in the Sociology of Organizations, 29, 265-275.

Prahalad CK (2005) The fortune at the bottom of the pyramid. Wharton School Publishing Upper Slade River

Prahalad, CK, \& Hart, SL. (2002). The fortune at the bottom of the pyramid. Strategy + Business, 26(2002), 54-67

Prahalad, CK, \& Hammond, A. (2002). Serving the world's poor, profitably. Harvard Business Review, 80(9), 48-57.

Quinn, R. (1996). Deep change: discovering the leader within. San Francisco: Jossey-Bass.

Rainey DL (2004) Sustainable development and enterprise management: creating value through business integration, innovation and leadership. Article presented at Oxford University at its colloquium on Regulating Sustainable Development: Adapting to Globalization in the $21^{\text {st }}$ Century - August 8 through 13, 2004 
Ricca, M, \& Robins, R. (2012). Meta-luxury: brands and the culture of excellence. London: Palgrave MacMillan.

Rinaldi, FR, \& Testa, S. (2014). The responsible fashion company: integrating ethics and aesthetics in the value chain. Sheffield: Greenleaf Publishing.

Schaltegger S, Ludeke-Freund F, Hansen, EG (2011) Business cases for sustainability and the role of business model innovation: developing a conceptual framework. Centre for Sustainability Management, Leuphana University of Lueneburg, Germany

Sneddon, C. \& Howarth, R.B. (2006) Sustainable development in a postBrundtland world, Ecological Economist, no. 57, pp. 253-268. Available at: http://www.sciencedirect.com/science/article/pii/S0921800905002053.

Stephen, L. (1996). Export markets and their effects on indigenous craft production: the case of the weavers of Teotitlán del Valle, México. In S Margot Blum, JC Berlo, \& EB Dwyer (Eds.), Textile traditions of Mesoamerica and the Andes: an anthology (pp. 381-402). Austin: University of Texas Press.

Stubbs, W, \& Cocklin, C. (2008). Conceptualizing a "Sustainability Business Model". Organization \& Environment, 21(2), 103-127.

Teece, DJ. (2010). Business models, business strategy and innovation. Long range planning, 43(2), 172-194.

Teece, DJ, Pisano, G, \& Shuen, A. (1997). Dynamic capabilities and strategic management. Strategic Management Journal, 18(7), 509-533.

World Commission on Environment and Development. (1987). Our common future. Oxford: Oxford University Press.

World Economic Forum. (2010). Redesigning business value: a roadmap for sustainable consumption. Geneva: World Economic Forum (WEF).

Wells, P. (2008). Alternative business models for a sustainable automotive industry. In A Tukker, M Charter, C Vezzoli, E Stø, \& M Andersen (Eds.), System innovation for sustainability. Sheffield: Greenleaf Publishing.

Wüstenhagen, R, \& Boehnke, J. (2008). Business models for sustainable energy. In A Tukker, M Charter, C Vezzoli, E Stø, \& M Andersen (Eds.), System innovation for sustainability. Sheffield: Greenleaf Publishing.

Zott, C, Amit, R, \& Massa, L. (2011). The business model: recent developments and future research. Journal of Management, 37, 1019-1042.

\section{Submit your manuscript to a SpringerOpen ${ }^{\circ}$ journal and benefit from:}

- Convenient online submission

- Rigorous peer review

- Immediate publication on acceptance

- Open access: articles freely available online

- High visibility within the field

- Retaining the copyright to your article

Submit your next manuscript at $\gg$ springeropen.com 